\title{
Econometric Approach of the Nexus Between Remittances and Economic Growth in Western Balkans
}

Submitted 11/01/20, 1st revision 30/01/20, 2nd revision 10/02/20, accepted 28/02/20

\author{
Rrezarta Gashi ${ }^{1}$, Liza Alili Sylejmani $^{2}$
}

\begin{abstract}
:
Purpose: The purpose of this research paper is to highlight the importance of remittances in the economic development of a country, with special emphasis in Western Balkan countries.

Design/Methodology/Approach: This paper is based on the study of theoretical issues, OLS model, fixed (FE) and random (RE) effect model. In addition Hausman test has been applied to determine the appropriate model among Fixed and Random effects. Revealing the results of the Hausman test the Random effect model is considered as the appropriate model, and it implies the existence of positive and significant relationship between remittances and GDP per capita growth in the Western Balkan countries for the time period 2000 - 2018.

Findings: Results based in OLS model findings reveal a positive relationship between remittances and GDP per capita growth. Also the results of the random and fixed effect model reveal positive and significant effect of remittances on the economic growth, thus by increasing remittances the GDP per capita will increase. The results also present that Gross Fixed Capital Formation has a positive impact on the economic growth, where by increasing Gross Fixed Capital Formation, the GDP per capita will increase.

Practical Implications: The results of this research are supportive regarding the relationship between remittances and economic growth, yet will contribute to the existing literature as well as for further policy recommendations by the Western Balkan countries.

Originality/Value: This research paper is an empirical analysis based on the data provided by the World Bank, for the time period 2000-2018.
\end{abstract}

Keywords: Remittances, growth, Fixed effect, Random effect, Western Balkans.

JEL Codes: F22, F24, F29.

Paper type: Research article.

\footnotetext{
${ }^{1}$ AAB College, Faculty of Economic Sciences, Kosovo, E-mail: rrezartag@gmail.com

${ }^{2}$ International Balkan University, Faculty of Economics and Administrative Sciences, North Macedonia, E-mail: liza.a.sulejmani@gmail.com
} 


\section{Introduction}

International transfers known also as remittances have attracted the attention of many different researchers from developed countries as well as from developing. Considering the living standard in developed countries in comparison to the developing countries, it is worth mentioning that the reasons for migration are continually increasing, resulting in an increase in remittances from these countries. Western Balkans are known as countries with high levels of emigration, hence a high level of remittances. Based on "Personal i Mynihut RePec" report in the end of 2013, 5.7 million people originating from the Western Balkans are currently living abroad, leading to an emigration rate for this year up to $31.2 \%$, starting from $18.2 \%$ of total population in Serbia to $45.3 \%$ prevalent in Montenegro.

After the dissolution of Yugoslavia, 3.5 million people left the region. The emigration level was $19.4 \%$, with Serbia having 9.1\% whereas Albania 38.5\%. This emigration level has led to a significant degree of payments, the entire region received 8.6 billion dollars in 2015, starting from 3.1\% of PBB in Northern Macedonia, while in Kosovo 16.7\% (Petreski et al., 2017). In the Central Bank's report on Western Balkans (2017) the remittances entry (as percent of GDP) is as follows:

Table 1. Remittance inflows (percent of GDP) - Western Balkan countries

\begin{tabular}{|l|l|l|l|l|l|l|l|}
\hline $\begin{array}{l}\text { Remittance inflows } \\
\text { (percent of GDP) }\end{array}$ & 2013 & 2014 & 2015 & 2016 & 2017 & 2018 & 2019 \\
\hline Albania & 6.9 & 7.2 & 7.5 & 7.2 & 7.5 & 7.4 & 7.1 \\
\hline B\&H & 8.1 & 8.5 & 8.3 & 8.2 & 8.0 & 7.9 & 7.9 \\
\hline Kosovo & 9.4 & 10.0 & 10.5 & 10.6 & 10.8 & 11.0 & 11.4 \\
\hline North Macedonia & 2.2 & 2.2 & 2.1 & 1.8 & 2.1 & 2.0 & 2.0 \\
\hline Montenegro & 4.6 & 4.3 & 4.1 & 3.8 & 3.7 & 3.7 & 3.5 \\
\hline Serbia & 6.3 & 5.6 & 6.2 & 5.1 & 5.7 & 5.7 & 5.5 \\
\hline
\end{tabular}

Source: World Bank, 2017.

Apart from individual benefits, remittances impact also the microeconomic level as well as the macroeconomic level of the economy. Regarding the microeconomic level, remittances bring high benefits to the checking accounts representing also a high percentage of GDP, on this level remittances positively affect the improvement of wellbeing, opportunities in educational level and in health. On the macroeconomic level, they are mostly addressed in the aggregate demand increase, whereby with an increase of the latter, there is an increase for producing and consuming and this is a result of several multipliers. Except for the positive impact of remittances, there are also negative effects whereby migrating abroad results also in the loss of the educated employees, known also as "brain drain" (Topxhiu and Krasniqi, 2017). 
The aim of this study is to bring to attention the impact of the remittances in the economic development of the countries of Western Balkans. This research is structured in five sections: the introduction, literature review regarding remittances and their impact in a country's economic development, methodology, findings and the discussions.

\section{Literature Review}

Remittances known in economic literature as emigration transfers that are very important for a country's economic development, especially when the developing countries are in question. Remittances play an important role in the economy, as seen by the increase in consumption, investments and a country's financial stability. Nowadays, they are not only used as mechanisms of survival in the developing countries, but are also a sustainable source of investments and consumption mitigation in the future (Ratha, 2003; Silva and Huang, 2006). Remittances known in the economic literature are very important for the economic development of a country, especially when it comes to developing countries.

Remittances play an important role in the economy by seeing them through the prism of growth of consumption, investment and financial stability of a country. In the research by Catrinescu et al. (2009) it is stated that the transfers can also impact negatively the economic growth of a country in the midterm or the long-term period, because the remittances can urge inflation as well as disadvantages in the country's market, as well as the decrease in the number of labor market sharers, because the families who receive remittances can choose to live by those. Many authors have analyzed different influencing factors on remittances and have categorized them in macroeconomic and microeconomic factors. In several studies by different authors, many characteristics of the senders of remittances have been addressed. Within the characteristics of the senders what it comes to attention are age, gender, marital status, status in the workplace, their revenues etc.

Microeconomic factors are related to the migration circumstances and the migrant's relation with their home, and macroeconomic determinators related to economic and political conditions in both countries, the origin and the hosting country (Lucas, 2004). Another important factor in the microeconomic factor analysis is undoubtedly the emigrants' education level. In their studies Nimmi et al. (2008), have confirmed that the fleeing of educated individuals can bring to a vaccuum in the country of origin, but also the quantity of the remittances from this level is much lower in comparison to the one sent by less educated emigrants. Regarding the macroeconomic factors of remittances, the high flux of transfers can have direct consequences in the foreign exchange rates, internal interest rates and payment balances, as well as indirect consequences that may be macrovariables (World Bank, 2006). According to research, remittances can act as a stabilizer in the receiving countries. Authors, Chami, Fullenkamp, and Jahjah (2005), Bouoiyour, Selmi, and Miftah (2018) claim that remittances may have a tendency to move against cyclical 
GDP with remittance recipient countries, where constantly there are implications of the model that remittances are compensating transfers. Based on the works of Matuzeviciute and Butkus (2016), Gashi (2018), it is said that the impact of macroeconomic factors can be positive and include: the increase of foreign investments, increase in the foreign currency rate, decrease of macroeconomic unsustainability and import increase, while as a negative impact can be considered the increase of the exchange rate, employment decrease, decrease in export competition and increase in the price level.

Meyer and Shera (2017) claim that remittances increase the consumption level of the rural families that may have crucial multiplier effects. These authors have also proved in their research of 1999-2013 for countries as Albania, Bulgaria, North Macedonia, Moldova, Romania and Bosnia Herzegovina through multiple regression analysis that remittances contribute positively and considerably in these countries' economic growth. So, the contribution of the remittances is the most significant and important in the country's economic growth. But its productive application can help the countries' economy to preserve and improve the economic growth by investing this money in consumption and various investments.

Based on the research of Singh et al. (2010) and Dridi et al. (2019), remittances can also increase the investment by decreasing the consumption unsustainability and by contributing in a more sustainable and favorable macroeconomic environment for investment activities.

\section{Research Methodology and Data}

Remittances represent an important external source of financial flow that especially has a crucial effect on the economic growth of developing countries. The economic theory implies that remittances can positively affect the economic growth as well as investment and consumption. In this regard, the model used in this research paper is based on this statement, representing the general shape of model equation. In this regard panel annual data are utilized for 6 countries in Western Balkans region: Albania, Bosnia, Montenegro, North Macedonia, Serbia and Kosovo, for the time spin of $2000-2018$. The panel is strongly balanced, implying same time period for all the countries included in the panel.

In order to accomplish the main objective of this research paper, fixed effect (FE) and random random (RE) effect models have been employed, while OLS model has been used for comparison purpose. Fixed effect model is appropriate when determining the explanatory variable as non - random variable, contrary to the random effect model that treats the explanatory variable to be derived from random occurrences. In addition, the fixed effect model investigates the type of the impact of the variables that change over time. Thus, it investigates the nexus among the independent variable and dependent variable within the same unit, by assuming that the countries might contain individual characteristics that can influence the 
independent variables. Therefore, the main objective of the fixed effect model is to check whether there exist a correlation between the error term and the independent variable, thus at the end to evaluate the net effect of the independent variables. On the other hand, the main assumption of the random effect model is that there exists a random or causal difference between the units (countries), that it is not correlated with the independent variables. In order to choose among the fixed and random effect model, Hausman test is performed.

Data set covers the recent annual data for the time spin 2000 -2018, for the Western Balkan region: Albania, Bosnia, Montenegro, North Macedonia, Serbia and Kosovo, collected from the indicators from the World Bank.

Figure 1. GDP per capita and remittances trends of Western Balkans
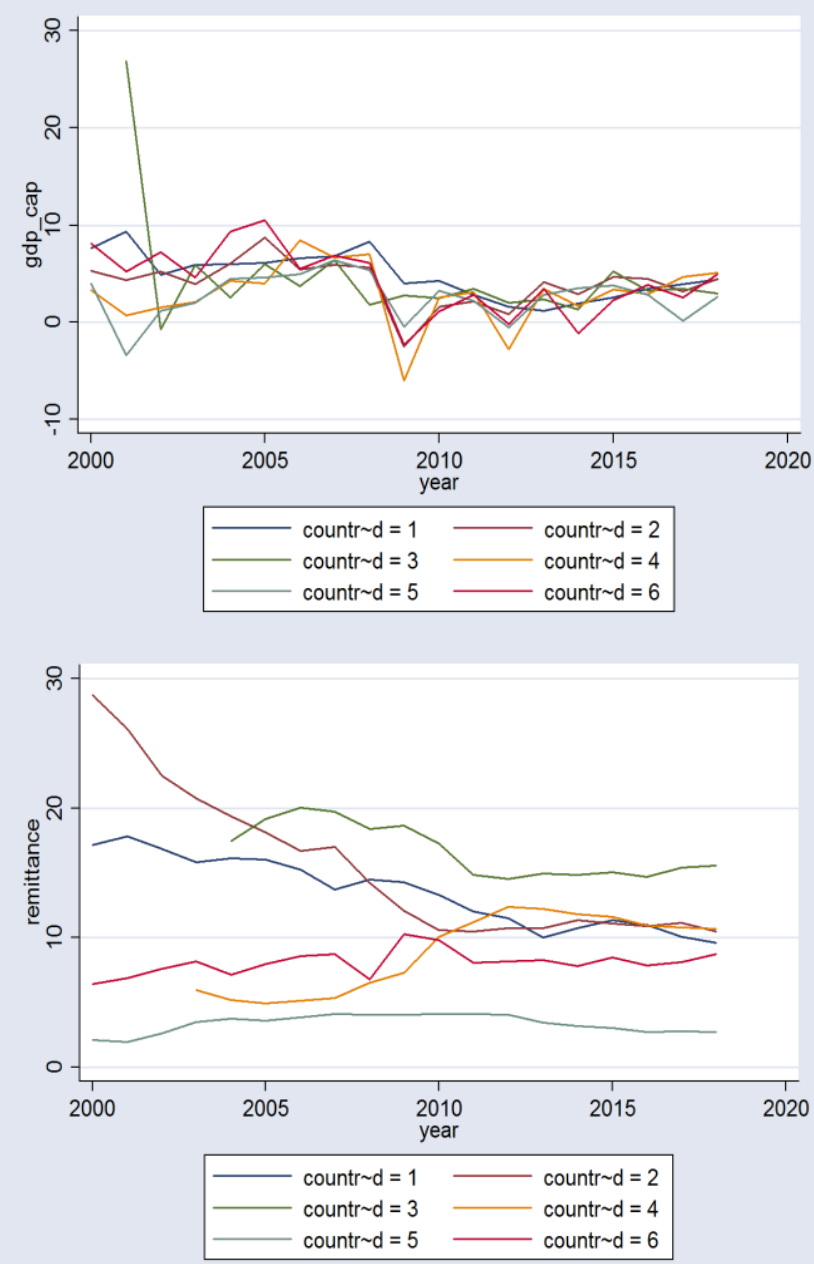

Source: Authors' source (World Bank data). 
In order to determine the impact of the remittances on the economic growth in the Western Balkans, following the methodology of Chami et al. (2003), Chami et al. (2005) and Meyer and Shera (2017), this research paper employs panel regression models OLS, Fixed (FE) and Random (RE) effects. In this regard, the following basic regression equation has been determined:

$$
\begin{aligned}
& \text { Gdp } p_{\text {cap }}=\beta_{0}+\beta_{1} \text { remmitance }+\beta_{2} g f c f+\beta_{3} \text { f consump }+ \\
& \beta_{4} \text { population }+\varepsilon
\end{aligned}
$$

where:

$\beta_{0}$ - intercept term;

gdp_cap - GDP per capita growth ( \% annual);

remittances - Personal remittances receipt (\% of GDP);

gfcf - Gross Fixed Capital Formation (\% of GDP);

fconsump - Final consumption expenditure (\% of GDP);

population - population growth ( annual \%);

$\varepsilon$ - error term.

In addition, the following table represents the expected relationship of the variables in the above model. Economic growth represents the dependent variable, measured through the GDP per capita growth rate (annual \%), while remittance represents the independent variable measured through personal remittances receipt (\% of GDP). As additional independent variables are gfcf that represents Gross Fixed Capital Formation as $\%$ of GDP, fconsump measures the final consumption expenditure as $\%$ of GDP and population that represents the population growth (annual percentage).

Table 2. Definition of variables, their abbreviations and expected relationship

\begin{tabular}{|l|l|l|}
\hline Variables & Abbreviation & Relationship \\
\hline GDP per capita growth rate (annual \%) & gdp_cap & \\
\hline Personal remittances receipt (\% of GDP) & remittance & positive \\
\hline $\begin{array}{l}\text { Gross Fixed Capital Formation as \% of } \\
\text { GDP }\end{array}$ & gfcf & positive \\
\hline $\begin{array}{l}\text { Final consumption expenditure as \% of } \\
\text { GDP }\end{array}$ & fconsump & positive \\
\hline Population growth (annual percentage) & population & negative \\
\hline
\end{tabular}

Source: Authors' calculations.

In addition, the following Table 3 represents the descriptive statistics of the variables, regarding the number of observations, their mean value, standard deviation, and their minimum and maximum value.

Table 3. Descriptive statistics

\begin{tabular}{llllll}
\hline Variables & Observations & $\begin{array}{l}\text { Mean } \\
\text { value }\end{array}$ & $\begin{array}{l}\text { Standard } \\
\text { Deviation }\end{array}$ & $\begin{array}{l}\text { Minimum } \\
\text { value }\end{array}$ & $\begin{array}{l}\text { Maximum } \\
\text { value }\end{array}$ \\
\hline
\end{tabular}




\begin{tabular}{llllll}
\hline gdp_cap & 113 & 3.862011 & 3.493825 & -5.996974 & 26.88778 \\
remittances & 107 & 10.86017 & 5.546285 & 1.979687 & 28.71385 \\
Gfff & 109 & 23.5759 & 13.16328 & -28.9021 & 79.78271 \\
fconsump & 112 & 98.17088 & 8.240793 & 79.56681 & 116.1335 \\
population & 114 & -.1528761 & .6320005 & -3.582128 & 1.041533 \\
\hline
\end{tabular}

Source: Authors' calculations.

\section{Empirical Findings}

Several econometric models have been employed in order to determine the relationship between remittances and economic growth in Western Balkans. In addition, the results of OLS, fixed effects and random effects are presented in Table 3. OLS findings reveal a positive relationship between remittances and GDP per capita growth, thus by increasing one point of the remittances the GDP per capita will increase by 0.1 point. In addition, adjusted $\mathrm{R}^{2}=0.719$, thus $71.9 \%$ of the estimated model explains the variances of the dependent variable - GDP per capita. In addition, positive and significant relationship is determined between gfcf and gdp_cap, where by increasing 1 point of Gross Fixed Capital Formation, the GDP per capita will increase by 0.08 point. Further, final consumption has positive but statistically insignificant effect on the economic growth, while population growth as expected has negative and significant effect on the economic growth of the Western Balkan countries.

The last two columns represent the Fixed effect and Random effect regression results. In addition, the last row represents the results of the Hausman test, indicating the Random effect model as appropriate. Thus, the null hypothesis individual effects are not correlated with other model repressor it cannot be rejected, thus Random effects model is suitable. Results of the Random effect model reveal positive and significant effect of remittances on the economic growth, thus by increasing one point of remittances the GDP per capita will increase by 0.11 point. In addition, Gross Fixed Capital Formation also has a positive impact on the economic growth, where by increasing one point of Gross Fixed Capital Formation, the GDP per capita will increase by 0.08 point. Population growth as expected it reveals negative effect on the growth, while final consumption does not have significant effect on the economic growth of Western Balkan countries.

Table 4. Regression results: OLS; fixed and random effects

\begin{tabular}{|llll|}
\hline Estimation model & OLS & $\begin{array}{l}\text { FIXED } \\
\text { EFFECTS }\end{array}$ & $\begin{array}{l}\text { RANDOM } \\
\text { EFFECTS }\end{array}$ \\
\hline $\begin{array}{l}\text { Dependent } \\
\text { variable: gdp_cap }\end{array}$ & & & \\
\hline remittances & $\mathbf{0 . 1 0 4 8 3 * *}^{* *}$ & $\mathbf{0 . 2 4 1 2 5 *}$ & $\mathbf{0 . 1 1 1 8 3 *}$ \\
& $(\mathbf{0 . 0 2 5 )}$ & $(\mathbf{0 . 0 0 7 )}$ & $(\mathbf{0 . 0 2 3})$ \\
gfcf & $\mathbf{0 . 0 8 4 0 *}^{*}$ & $\mathbf{0 . 0 9 3 1 3 *}^{*}$ & $\mathbf{0 8 2 7 4 5 *}$ \\
\hline
\end{tabular}




\begin{tabular}{|c|c|c|c|}
\hline \multirow{3}{*}{ fconsump } & $(0.000)$ & $(0.000)$ & $(0.000)$ \\
\hline & 0.00504 & 0.05484 & -0.00873 \\
\hline & $(0.490)$ & $(\mathbf{0 . 3 1 8})$ & $(\mathbf{0 . 7 9 7})$ \\
\hline \multirow[t]{2}{*}{ population } & $-0.81972 * * *$ & -0.79143 & $-0.79291 * * *$ \\
\hline & $(0.058)$ & $(0.247)$ & $(0.068)$ \\
\hline observation & 107 & 107 & 107 \\
\hline Adjusted R- & 0.719 & & \\
\hline $\begin{array}{l}\text { squared } \\
\mathrm{F}\end{array}$ & 69.45 & 7.65 & \\
\hline Wald Chi2 & & & 29.42 \\
\hline Model & OLS & FE & RE \\
\hline \multicolumn{4}{|l|}{ Hausman test } \\
\hline \multicolumn{4}{|l|}{ Chi2 $=5.86$} \\
\hline \multicolumn{4}{|c|}{ Prob $>$ chi $2=0.2096$} \\
\hline \multicolumn{4}{|c|}{ Random effect appropriate } \\
\hline \multirow{3}{*}{\multicolumn{4}{|c|}{$\begin{array}{l}\text { Breusch and Pagan Lagrangian multiplier test for random effects } \\
\text { chibar2 }(01)=0.00 \\
\text { Prob }>\text { chibar } 2=1.0000\end{array}$}} \\
\hline & & & \\
\hline & & & \\
\hline \multicolumn{4}{|c|}{$\begin{array}{l}\text { Note: }(*) \text { statistically significant at } 1 \% \text { level, }(* *) \text { statistically significant at } 5 \% ;(* * *) \\
\text { statistically significant at } 10 \%\end{array}$} \\
\hline
\end{tabular}

Source: Author's calculations.

\section{Discussion}

The main aim of the research paper was to investigate the relationship of the remittances and economic growth in Western Balkan countries, Albania, Bosnia and Herzegovina, Montenegro, North Macedonia, Kosovo and Serbia, by utilizing recent data of the World Bank indicators for the time period 2000 - 2018. In this regard, several models have been used OLS, Fixed and Random effects. In addition, Hausman test has been determined in order to choose the appropriate model between Fixed and Random effects, determining the Random effects as the suitable one. Finally, the results reveal positive and significant relationship between remittances and economic growth in Western Balkans, for the time period $2000-2018$.

In addition, the positive and significant effect of investment and insignificant effect of consumption reveal the need of the government to address the changes in the policies, yet keeping into consideration the short effect of consumption in the economic growth in the developing countries. A special recommendation from this research for Western Balkan countries is for these countries to have a special plan from the government for investments from remittances, since they are of high value, a special promotion for these investments to take place, because their potential is quite large, then ease of money transfers through commercial banks, meaning with lower costs.

\section{References:}


Bank, W. 2017. Western Balkans-Regular Economic Report No.12. World Bank Group.

Bouoiyour, J., Selmi, R., Miftah, A. 2018. The relationship between remittances and macroeconomic variables in times of political and social upheaval: Evidence from Tunisia's Arab Spring. Economics of Transition and Institutional Change , 355394. At: https://doi.org/10.1111/ecot.12199; https://doi.org/10.1111/ecot.12199.

Catrinescu, N., Ledesma, M.L., Piracha, M., Quillin, B. 2009. Remittances, Institutions, and Economic Growth. World Development, 37(1), 81-92.

Chami, R., Fullenkamp, C., Jahjah, S. 2005. Are Immigrant Remittance Flows a Source of Capital for Development? International Monetary Fund, IMF Staff Papers, 52(1), 55-81.

Chami, R., Fullenkamp, C., Jahjah, S. 2003. Are Immigrant Remmitance Flows a Source of Capital for Development. International Monetary Fund-IMF Working Paper.

Dridi, J., Gursoy, T., Saiz, H.P., Bari, M. 2019. The Impact of Remittances on Economic Activity: The Importance of Sectoral Linkages. IMF Working Paper, 7.

Gashi, R. 2018. Remittance Incomes and Economic Development in Kosovo. Prizren Social Science Journal, 2(2), 43-51. At: https://doi.org/10.32936/pssj.v2i2; https://doi.org/10.32936/pssj.v2i2.

Lucas, R. 2004. www.un.org. Retrieved June 2020, https://www.un.org/en/development/desa/population/events/pdf/3/P22_AnnexIII. pdf.

Matuzeviciute, K., Butkus, M. 2016. Remittances, Development Level, and Long-Run Economic Growth. Economies, 2-20.

Meyer, D., Shera, A. 2017. The impact of remittances on economic growth: An econometric model. Economia , 147-155. At: https://doi.org/10.1016/j.econ.2016.06.001; https://doi.org/10.1016/j.econ.2016.06.001.

Petreski, M., Petreski, B., Tumanoska, D., Narazani, E., Kazazi, F., Ognjanov, G. 2017. The size and effects of emigration and remittances in the Western-Balkans: Forecasting based on a Delphi process. Munich Personal RePEc Archive.

Ratha, D. 2003. Workers' Remittances: An Important and Stable Source of External Development Finance. World Bank.

Remittances and the Brain Drain: Skilled Migrants Do Remit Less, No. 3393. 2008.

Silva, C.V., Huang, P. 2006. Macroeconomic Determinants of Workers' Remittances: Host vs. Home Country's Economic Conditions. Journal of International Trade and Economic Development, 15(1), 81-99. DOI: 10.1080/09638190500525779.

Singh, R.J., Haacker, M., Lee, K.W., Goff, M.L. 2010. Determinants and Macroeconomic Impact of Remittances in Sub-Saharan Africa. Journal of African Economies, 20 (2), 312-340. doi:10.1093/jae/ejq039.

Topxhiu, R.M., Krasniqi, F.X. 2017. The Relevance of Remittances in Fostering Economic Growth in the West Balkan Countries. Ekonomika, 96(2), 28-42. DOI: https://doi.org/10.15388/Ekon.2017.2.10989.

World Bank. 2006. www.worldbank.org. Retrieved June 2020, from http://documents1.worldbank.org/curated/en/507301468142196936/841401968_2 00510319015205/additional/343200GEP02006.pdf. 